\title{
Diversidade sexual e de gênero no ensino de artes visuais para as infâncias: formalismo como elemento de estabilidade nos currículos*
}

DIVERSIDAD SEXUAL Y GÉNERO EN LA ENSEÑANZA DE LAS ARTES VISUALES EN LA INFANCIA: FORMALISMO COMO ELEMENTO DE ESTABILIDAD EN LOS CURRÍCULOS

SEXUAL DIVERSITY AND GENDER IN THE TEACHING OF VISUAL ARTS FOR THE CHILDHOODS: FORMALISM AS ELEMENT OF STABILITY IN THE CURRICULUM

\section{Edvandro Luise Sombrio de Souza** Monique Andries Nogueira***}

Cuadernos de Música, Artes Visuales y Artes Escénicas / Volumen 13 - Número 1 / Enero - Junio de 2018

/ ISSN 1794-6670/ Bogotá, D.C., Colombia / pp. 149-172

Fecha de recepción: 27 de junio de 2017

Fecha de aceptación: 17 de septiembre de 2017

Disponible en línea: 6 de diciembre de 2017

doi:10.11144/javeriana.mavae13-1.dsgn (UEL), Mestre em Educação pela UFRJ; professor de Artes Visuais do Colégio Pedro II. 


\section{Resumen}

Este artículo trata de la temática de la diversidad sexual y de género en la enseñanza de artes visuales para niños. Tiene como objetivo analizar los programas de primaria de tres escuelas públicas de la ciudad de Río de Janeiro. Nosotros intentamos comprender cómo el género y la sexualidad son tratados por ellos, en articulación con las categorías etnia, raza y clase social, utilizando el concepto de estabilidad (Goodson 1997). Partimos del abordaje de la idea de "frontera" (Louro 2015), de la teoría queer, en contacto con el campo de la educación, para cuestionar las bases epistemológicas del constructo de ideas, conceptos, conocimientos, áreas y prácticas sociales. Echamos una mirada hacia estas fronteras en el campo del arte y levantamos cuestiones acerca de las nociones de "niñez" que establecemos en las escuelas (Felipe 2006) y sus relaciones con el género y la sexualidad.

Palabras claves: género; sexualidad; curículo; niñeces; educación artística

\section{Abstract}

This article deals with the theme of sexual diversity and gender in the teaching of Visual Arts for the childhood. It aims to analyze the programs for the earliest years of Elementary Education of three public schools in the city of Rio de Janeiro. We tried to understand how gender and sexuality are handled by them, in conjunction with the categories ethnicity, race and social class, using the concept of the formalism as element of stability (Goodson 1997). We set out the approach of "border" (Louro 2015), from queer theory, in contact to the field of Education, to question epistemological bases of construction of notions, concepts, knowledge, camps and social practices. We look at these borders in field of Art and raised questions about notions of childhood present in schools (Felipe 2006) and their relationship to gender and sexuality.

Keywords: gender; sexuality; curriculum; childhood; visual arts teaching

\section{Resumo}

O presente artigo trata da temática da diversidade sexual e de gênero no Ensino de Artes Visuais para as infâncias. Tem como objetivo analisar os programas para os Anos Iniciais do Ensino Fundamental de três escolas públicas da cidade do Rio de Janeiro. Buscamos compreender como gênero e sexualidade são tratadas por eles, em articulação com as categorias etnia, raça e classe social, a partir do conceito de formalismo como elemento de estabilidade (Goodson 1997). Partimos da abordagem da noção de "fronteira" (Louro 2015), da teoria queer, em contato com o campo da Educação, para questionar bases epistemológicas da construção de noções, conceitos, conhecimentos, áreas e práticas sociais. Lançamos um olhar para estas fronteiras no campo da Arte e levantamos questões sobre as noções de "infâncias" que exercitamos nas escolas (Felipe 2006) e suas relações com gênero e sexualidade.

Palavras chave: gênero; sexualidade; currículo; infâncias; ensino de artes visuais 


\section{INTRODUÇÃO}

Araújo \& Santos $(2009,18)$, ao discutir possibilidades contemporâneas de inclusão das questões de gênero e sexualidade na educação escolar brasileira, afirmam que "não podemos nos restringir a fatores que são, muitas vezes, consequências de outros dois muito mais amplos: as relações entre os gêneros e o desejo afetivo-sexual." Porém, esta transformação não diz respeito somente ao foco, mas, também, a questionamentos diretos à construção do conhecimento nas diversas áreas, ou seja, a uma mudança epistemológica. Segundo César $(2009,57)$ :

Os limites do discurso do sexo são marcados por sua concepção naturalizada, a-histórica e consequentemente imutável. Nessa perspectiva o sexo está confinado a sua percepção biológica, delimitando uma fronteira entre os sujeitos, masculino/feminino, heterossexual/homossexual e normal/anormal.

O caráter heteronormativo da construção do conhecimento tem ligação direta com o paradigma moderno das ciências naturais. Em seu caráter universalista, naturalizador e unificador, realiza processos de hierarquização de conhecimentos, de sujeitos e de objetos de estudo; opera em uma lógica que considera tudo o que está fora de seu alcance como "estranho" à Ciência, à Filosofia e à Arte; não permite relações entre sujeito e objeto do conhecimento, dentre tantos outros procedimentos que colocam grupos sociais e certos conhecimentos "para fora". Com os estudos feministas, gays, lésbicos, de gênero e queer, vemos uma série de movimentos de questionamento à construção epistemológica e, por consequência, nas práticas sociais (incluindo as práticas educativas). Conforme afirma Louro (2012, 367):

Trata-se de pôr em questão o que é conhecido e as formas como chegamos a conhecer determinadas coisas e a não conhecer (ou a desconhecer) outras. Isso significa questionar sobre as condições que permitem (ou que impedem) o conhecimento. Quais as condições que possibilitaram que determinadas noções fossem tomadas como verdades e, mais do que isso, fossem consideradas importantes e indispensáveis para serem introduzidas nos currículos e transmitidas de geração a geração? Quais as condições que empurraram para o silêncio outros saberes, que os esconderam ou secundarizaram na sistematização das disciplinas?

Trabalhando teoricamente no contexto da educação, Louro (2011) propõe que as formas como olhamos para os conhecimentos e os introduzimos nos currículos exercitam "pedagogias culturais, de gênero e de sexualidade". Ou seja, toda forma de construção e hierarquização de conhecimentos contém, em si, uma visão do que é uma mulher, um gay e uma lésbica, um negro e uma negra, um indígena e uma indígena, assim como uma noção do que sejam estes sujeitos enquanto objeto do conhecimento científico e das formas como podem participar das diversas instâncias de formação dos indivíduos e da sociedade; explícita ou implicitamente. E a educação escolar, neste contexto, tem um papel essencial como lugar de exercício e afirmação destas pedagogias.

Joan Scott lança importante discussão sobre a necessidade de tomar a perspectiva dos estudos de gênero como categoria analítica. Para ela, o gênero é compreendido como um "elemento constitutivo de relações sociais fundadas sobre as diferenças percebidas entre os sexos (e como) um primeiro modo de dar significado às relações de poder" (Scott 1995, 14). Compreender se determinados conhecimentos são construídos a partir de um ponto de vista comumente compreendido como feminino ou masculino, ou a própria defesa destes bi- 
narismos (feminino/masculino, homossexual/heterossexual, macho/fêmea, biológico/cultural), reflete um posicionamento/contexto histórico, teórico, social; e está relacionado a divisões de poderes. Nesta perspectiva é essencial questionar-se sobre sujeitos e objetos do conhecimento. Sob determinadas visões históricas, o produtor e/ou produtora deste ou daquele conhecimento era/é/se vê/apresenta como um homem ou uma mulher? Que lugar era/é dado ao homem e à mulher, em determinada sociedade, na produção dos conhecimentos científicos? Esta ciência, quando produzida por mulheres, reflete que tipo de visão sobre o feminino e a feminilidade? Como a mulher é tratada enquanto objeto do conhecimento?

Ao estudar a teoria queer, a partir de Guacira L. Louro, nos interessamos pela ideia de fronteira, um "lugar de relação, região de encontro, cruzamento e confronto [...] [que se] compraz da ambiguidade, da confusão, da mixagem" (Louro 2015, 20). Podemos estabelecer fronteiras entre os conhecimentos, nos sujeitos, nas práticas sociais e educacionais, nos movimentos sociais que exigem realizam a construção de teorias, nas ações afirmativas e no campo da Arte.

Ao falar sobre a figura da drag, persona que transita, que parodia as relações de gênero, Louro $(2015,21)$ propõe que, para elas, "a fronteira está muito perto e que pode ser visitada a qualquer momento". Não ocorreria o mesmo com o conhecimento? Tudo o que conhecemos sobre os sujeitos e objetos de conhecimento não poderia ser deslocado para estas fronteiras? A prática de ensinar não pode ser realizada aí, no limite, no lugar de conflito? Não seria uma necessidade da Educação? Louro nos fala da dificuldade de falar da teoria queer no campo da Educação, pois este seria um lugar de prescrições e categorizações, enquanto o queer é um lugar de movimento constante, um "colocar-se contra a normalização - venha ela de onde vier" (Louro 2015, 39). O próprio campo das legislações educacionais, dos movimentos sociais e dos Direitos Humanos, por exemplo, carecem e se valem destes "portos seguros", destas construções culturais que são as identidades. Assumimos, desde já, para este trabalho, que não é possível falar de um currículo inclusivo, intercultural, que trate das questões de gênero e de sexualidade sem nos valer da identidade como estratégia.

Tendo em vista a ideia de fronteira, da necessidade de tratarmos da constituição de campos de conhecimento e da relação entre eles, neste artigo, compreendemos que noções como arte, infâncias (público ao qual nos dedicamos na atividade de lecionar) e tantas outras, são construções culturais. Por isso, partimos de breve exposição sobre a noção de fronteira no campo da Arte, com especial interesse na arte contemporânea, como locus de exercício e discussão de formas variadas de viver e de articulações com movimentos sociais e identitátios, a partir, aproximadamente, da década de 1960. Em seguida, abordamos noções de infâncias e algumas possíveis relações com as categorias gênero e sexualidade. Lançamos, então, nosso foco para o Ensino de Artes Visuais no Brasil, a partir de autoras e autores como Loponte (2002), Louro (2015), Dias (2006) e Richter (2000), percebendo que o deslocamento para estas "fronteiras" nos coloca em contato com outras categorias teóricas e práticas sociais do campo da Arte, sua história e seu ensino. Enfim, a partir de Goodson (1997), autor do campo do currículo, realizamos uma crítica ao formalismo, como estruturante de programas curriculares da disciplina Arte ou Artes Visuais, ainda contemporaneamente. 


\section{FRONTEIRAS NO CAMPO DA ARTE}

Não podemos falar sobre Ensino de Artes Visuais sem antes questionar o próprio estatuto da Arte. Como este campo se constituiu? Como estabeleceu suas "fronteiras"? Conforme nos diz Loponte $(2008,156)$ :

\footnotetext{
Mais do que discursos que apenas refletem ou nomeiam uma determinada realidade, as imagens criadas pelos artistas produzem verdades sobre sujeitos, produzem práticas sociais. Há vários discursos em disputa na definição do que é digno de ser representado ou de quem pode representar nas artes visuais, e essas práticas de poder articulam-se à produção de verdades sobre gênero e sexualidade. No entanto, se as relações de poder pendem em determinados períodos históricos e culturais para um determinado modo de ver, isto não quer dizer que assim o sejam indefinidamente. Não há um discurso monolítico e inabalável sobre a arte, imune a fraturas, resistências, deslocamentos.
}

Não há como tratarmos de questões de gênero e sexualidade sem suspender este olhar naturalizado que muitas vezes lançamos para a Arte, como se fosse um campo de conhecimento e ação humana "que sempre esteve aí," que não fosse uma produção da cultura e, ademais, de um tipo de cultura bastante específico. Pierre Bourdieu $(1990,122)$, ao tratar da noção de campo científico, nos fala que "[...] o universo 'puro' da mais 'pura' ciência é um campo social como qualquer outro, com suas relações de força e monopólios, suas lutas e estratégias, seus interesses e lucros, mas onde todas essas invariantes revestem formas específicas.". Assim como ocorre com o campo da Ciência analisado por Bourdieu, o campo da Arte tem uma história, genealogia e processos de luta, de redefinições, de afirmação de poderes. Jorge Coli $(2006,15)$ afirma que

[...] no passado [...] a obra-prima era aquela que coroava o aprendizado de um ofício, que testemunhava a competência de seu autor. Não se tratava de uma realização forçosamente inovadora, original, e era com frequência um produto utilitário, saído das mãos de um carpinteiro, ourives, tecelão.

O autor nos fala que, até aproximadamente o século XIV, a ideia da arte como um campo separado, da contemplação de um objeto com uma aura, quase uma vida; do estilo do artista ou outras tão caras ao campo da Arte não existiam. O que hoje chamamos de Arte não passava de mais um aspecto da produção manual entre tantos outros das corporações de ofício da Idade Média, ou seja, não havia uma hierarquia de importância em se fazer um sapato ou uma escultura, por exemplo. A própria ideia de "assinar uma obra", de "imortalizar" as produções de um artista nasce aí.

O Renascimento, período que se estende, aproximadamente, entre meados do século XV até meados do século XVI, pode ser entendido como fase de produção deste campo - a Arte; suas "linguagens" (pintura, escultura, gravura e arquitetura) e a crítica (Coli, 2006). A constituição das instituições artísticas que conhecemos hoje - museus, galerias, espaços culturais - ainda demorariam alguns séculos para acontecer, assim como o campo da História da Arte, que "traria para a Arte" objetos produzidos em outras épocas ou culturas, estabelecendo certas hierarquias entre os objetos "artísticos" ou "não-artísticos". Assim, só é possível tratar de uma arte pré-histórica ou egípcia, por exemplo, se nos valemos dos critérios do campo da História da Arte, já que estas civilizações não produziram nenhum objeto com a ideia de "produzir arte." Do mesmo modo, contemporaneamente, só podemos falar de uma arte indígena (ou ameríndia), por exemplo, se nos posicionamos em um ponto de vista ocidental específico, já que, 
[...] a maior parte das culturas não ocidentais não têm uma palavra para designar o que nós chamamos "arte" [...] Os indígenas e outros povos não-ocidentais não fazem objetos que servem só para serem contemplados. Tudo o que fabricam tem que ser bonito e, além de bonito, bom (Silva \& Grupioni 1995, 374).

Enfim, o campo da Arte passaria por uma série de redefinições até nossa época. Tendo em vista os temas deste artigo, lançaremos um breve olhar sobre a arte contemporânea, percebendo que, talvez, o contexto da produção e circulação artística tenha se apresentado, desde, pelo menos, a década de 1960, como um dos mais frutíferos para o exercício, discussão e afirmação de diferentes concepções sobre as relações de gênero e sexualidade, especialmente a partir de "exercícios de si." Muitos foram os artistas e coletivos que trataram, através de experiências subjetivas e particulares, de descolamentos, resistências, outras verdades sobre gênero e sexualidade. São artistas que trouxeram "para dentro da Arte" uma série de lutas políticas, sociais e identitárias, criando pedagogias que pouco têm sido discutidas nas pesquisas e práticas de Ensino de Artes Visuais. Estes artistas realizaram suas poéticas a partir de questões/técnicas eminentemente artísticas e suas proposições, como não poderia deixar de ser, alteraram a própria visão institucionalizada de Arte, o campo da Arte.

Anne Cauquelin (2005, 9-19), propõe que o que chamamos atualmente de arte contemporânea não diz respeito exclusivamente àquela que é produzida hoje. A ideia de contemporâneo, na arte, diz respeito a uma "pluralidade incontrolável de agoras" $(2005,12)$; uma quebra da valorização de um progresso histórico no que tange às formas de fazer e de pensar arte; a uma experimentação constante; à ligação com determinados sistemas que decidem o que é, e o que não é, arte - as instituições museológicas, galerias, marchands, publicações especializadas, casas de leilões, eventos internacionais; a apropriações materiais e imateriais, inclusive de formas e valores culturais, identidades; a maneiras bastante particulares de fazer arte e à necessidade de educar o público para frui-la; todas operações que se instalam no interior das obras, que as constituem.

As questões de gênero e sexualidade, para estes artistas e coletivos, não são "novos temas". Um dos grandes "problemas" ao qual artistas contemporâneos tem se dedicado é a questão de limites/fronteiras - entre as linguagens artísticas, na relação objeto de arte/público, nos materiais e técnicas. Clement Greenberg (in Battcock 1986), ao se debruçar sobre a arte contemporânea nascente, na década de 1960, nos fala que a arte moderna defendia uma ideia de "pureza," "essência" de cada linguagem. Ou seja, à pintura caberia criticar-se a partir da exploração empírica da planaridade, de sua bidimensionalidade, seus aspectos mais essenciais, formais. Uma obra de pintura que realizasse este processo se "autodefiniria," teria qualidade. Ao se produzir, ao se analisar uma pintura, estaríamos tratando de questões relacionadas à cor, à forma, a suportes tradicionais; à escultura aplicaríamos critérios de utilização de materiais, à exploração do espaço tridimensional e às formas de construir bases/pedestais, por exemplo. Os limites entre pintura e escultura, neste caso, estariam bem delimitados.

Rosalind Krauss (2001), em 1977, ao falar sobre o campo ampliado na escultura, vem tratar desta abertura no conceito de escultura e aborda artistas que realizam processos de hibridação entre pintura/escultura, escultura/arquitetura, por exemplo, ou seja, quebram fronteiras. Ela trata de um historicismo na crítica de arte, insistente na operação de fazer analogias com o passado:

O novo é mais fácil de ser entendido quando visto como uma evolução do passado [...] nos conformamos com essa percepção de similitude, com essa estratégia para reduzir tudo que nos é estranho, tanto no tempo como no espaço, àquilo que já conhecemos (Krauss 2001, 129). 
É importante ressaltar que Krauss escreve em um momento em que a ideia de originalidade, de vanguarda, de inovação (eminentemente modernistas, no sentido comumente tratado pelo campo da História da Arte) ainda é muito forte. Contudo, saindo um pouco do campo da Arte sem abandoná-lo, questionamos: nosso olhar de senso comum de século XXI não estaria ainda visando as diversidades sexuais e de gênero com esta mesma estranheza, esta necessidade de buscar "explicações no passado", de entender esta "novidade" na sociedade? Como superar esta necessidade historicista de colocar tudo em uma linha de tempo estável, como se fosse possível, a partir daí, depreender alguma segurança, imparcialidade, universalidade, estabilidade? O "passado", a História, também não são produções culturais?

Por que apresentar este contexto nesta pesquisa? Em primeiro lugar, para nós, esta quebra de fronteiras entre as linguagens artísticas equivale à necessidade de analisar uma série de limites/fronteiras que estabelecemos entre os sujeitos e nos sujeitos com relação às possibilidades de exercício/leitura de gêneros e de sexualidades. Em segundo lugar, estes artistas, à sua época, exigiram da crítica e das teorias da Arte que estas se refizessem. O entendimento sobre o que poderia ser considerado arte teve que se transformar e todas as instituições com poder para decidir sobre o assunto tiveram que se adaptar. Ou seja, trata-se de uma mudança epistemológica, de redefinições de um campo do conhecimento.

A potencialização deste exercício político direto, por artistas e coletivos, também exigia (e ainda exige) a criação de novas linguagens, novos suportes e materiais, novas formas de fazer e analisar arte, quebras as mais diversas nas fronteiras do campo da Arte. Apreciemos o trabalho de Beth Moysés, artista brasileira que "desde meados dos anos 1990 [...] tem utilizado o vestido de noiva como matéria-prima para discutir e ampliar questões sobre o desejo, o amor, a condição feminina e a violência doméstica" (Canton 2011, 45). Na performance Memória do Afeto, de 2000, cento e cinquenta mulheres vestidas de noiva, despetalando buquês, andaram por ruas do centro de São Paulo:

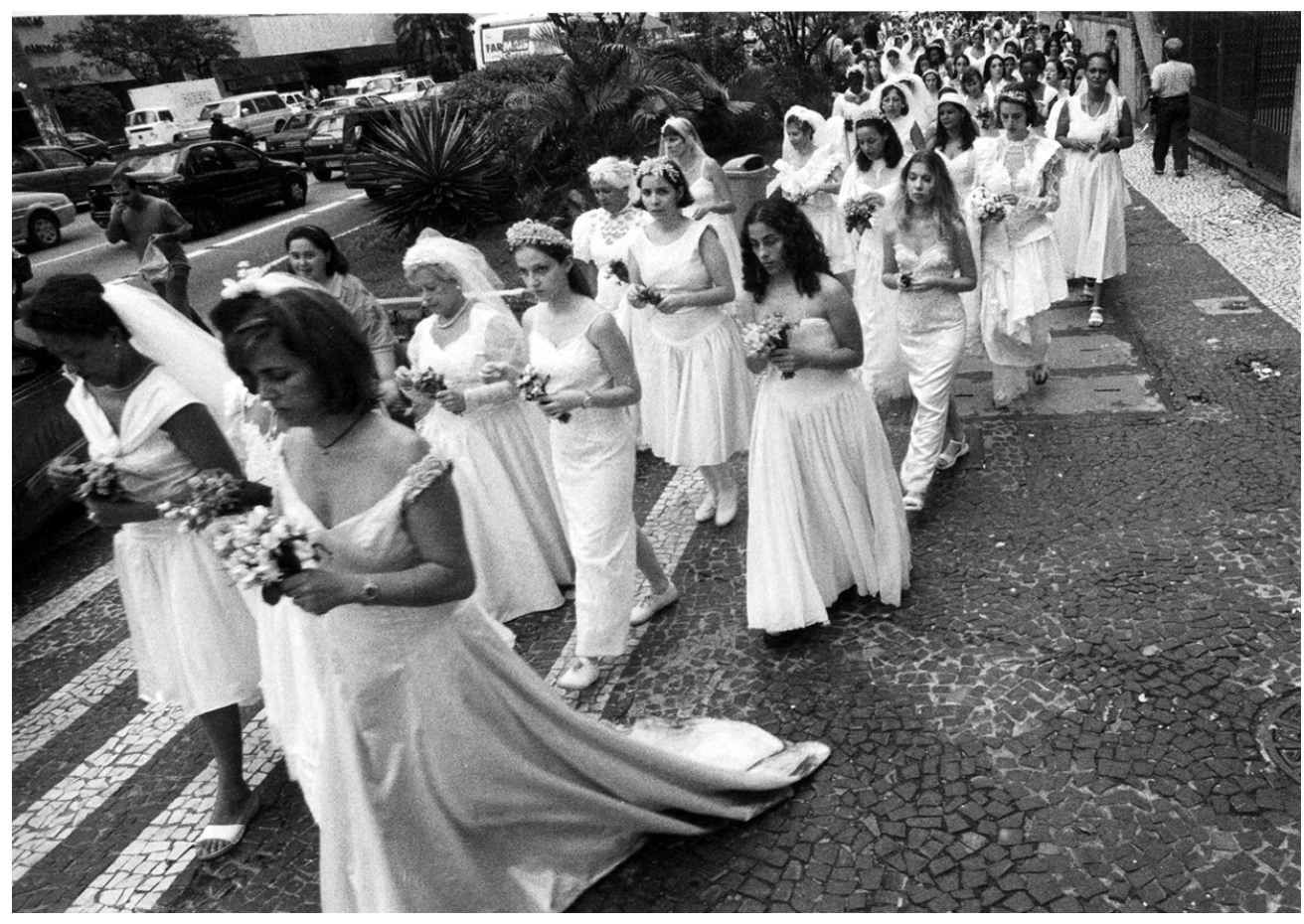

Beth Moysés, Memória do Afeto. Performance, 2000 (Foto' : Patrícia Gato). 
Sardelich (2006), ao tratar de concepções sobre o Ensino de Artes Visuais ligados à leitura de imagens, nos fala de tendências focadas em aspectos formais, ainda bastante influentes no campo e nas práticas pedagógicas em Arte, que impossibilitam docentes desta disciplina escolar de se aproximar das obras da arte contemporâneas, das culturas populares e da cultura visual. Nestas práticas, ainda é muito comum a tentativa de se aproximar de trabalhos contemporâneos a partir da análise e valorização de aspectos essenciais das linguagens artísticas as quais estas obras, ações e objetos extrapolam. Como analisar com olhos "modernos", formalistas, uma obra de performance, por exemplo, que, poderíamos dizer, une Artes Visuais e Teatro e, ademais, é filmada e/ou fotografada? Como realizar uma docência em Artes Visuais que leva em consideração as questões de gênero e sexualidade, se o professor ou a professora de Arte só as vê como temas e não como constitutivos da linguagem? Como elaborar currículos que superem visões formalistas e essencialistas sobre a Arte? Como falar do trabalho acima em termos exclusivamente formais? Que potência visual as questões tratadas por ele teriam se uma quebra de fronteiras entre linguagens não tivesse acontecido? Não se trata, aqui, da criação de novas linguagens? Ou melhor: de uma redefinição no campo das Artes Visuais (e de outras linguagens artísticas)?

A "pluralidade de agoras" referente à arte contemporânea é a mesma que vem sendo tratada nas teorias que se relacionam às diversidades, à diferença, aos estudos de gênero e queer, por exemplo. Entender que cada sujeito é um universo de possibilidades em que se cruzam diversos signos culturais: este é um trabalho que a arte contemporânea concretiza, dando a ver ao público uma gama imensa de possibilidades de ser, de estar, de circular pelo mundo e que urge ser exercitado nos mais variados contextos de Ensino de Artes Visuais.

Tendo em vista a necessidade de tratar destas "pluralidades de ser no mundo," e com o intuito de focalizar os sujeitos desta pesquisa: crianças que estudam nos Anos Iniciais do Ensino Fundamental"; a seguir, trataremos sobre noções de "infâncias", em relação com as questões de gênero e sexualidade, na educação brasileira.

\section{INFÂNCIAS, SEXUALIDADE E GÊNERO}

Noções como infância, juventude, maturidade e velhice são construções e só fazem sentido dentro de determinados contextos históricos e culturais. Souza $(2006,199)$ propõe que

[...] a "criança" de qualquer pedagogia já está, ao mesmo tempo, codificada como uma criança generificada [gendered], sexuada e racializada. Nesse sentido, a "criança" se torna um dos constructos mais normalizados e regulados da educação. (Souza 2006, 199)

Sobre o "sentimento de infância", Ariès (1981) nos conta de sua criação paulatina, da Idade Média, quando a criança não era mais que um "adulto em miniatura", até os tempos modernos, em que "a criança [passa a ser] vista como incapaz, frágil, um sujeito em desenvolvimento e que, portanto, ainda não o é; um sujeito a ser corrigido, educado, para se tornar 'Homem'" (Moruzzi 2010, 1).

Michel Foucault, ao tratar do dispositivo de sexualidade nos diz que, a partir do século XVIII, quando a sexualidade passa a permear todas as esferas da experiência humana ocidental, há quatro "grandes conjuntos estratégicos, que desenvolvem dispositivos específicos de saber e poder a respeito do sexo" (Foucault 2012, 114-116): a) Histerização do corpo da mulher; b) Pedagogização do sexo da criança; c) Socialização das condutas de procriação e d) Psiquizatrização do prazer perverso. Sobre o segundo item, que aqui nos interessa: 
[...] dupla afirmação, de que todas as crianças se dedicam ou são suscetíveis de se dedicar

a uma atividade sexual; e de que tal atividade sexual, sendo indevida, ao mesmo tempo "natural" e "contra a natureza", traz consigo perigos físicos e morais, coletivos e individuais; as crianças são definidas como seres sexuais "liminares", ao mesmo tempo aquém e já no sexo, sobre uma linha perigosa de demarcação; os pais, as famílias, os educadores, os médicos e, mais tarde, os psicólogos, todos devem se encarregar continuamente desse germe sexual precioso e arriscado, perigoso e em perigo. (Foucault 2012, 115)

Este "sentimento" também institui algumas ideias do que seria "uma infância", um menino, uma menina. Apoiando-se em Foucault e Butler, Moruzzi (2010) prefere tratar de "infâncias", no plural, propondo que diferentes crianças habitam e exercitam diferentes formas de produzir este "ser criança". Para ela, "o sexo já nasce gênero" (10) e o qualitativo feminino ou masculino é o primeiro a ser atribuído, desde a gestação. A partir daí, uma série de ações serão realizadas para afirmar este qualitativo - cores, brincadeiras, reações (como chorar), atitudes (ser mais dócil ou mais agressivo) - sendo confirmadas e reafirmadas constantemente, em diversas instituições, para definir aquele ser como menino ou menina. Esta relação binária é fixa e vista como "natural", sem possibilidades de trânsito entre os gêneros. O contexto familiar, a escola e as mídias são alguns locais em que discursos e linguagens exercitarão formas de produzir e, principalmente, reproduzir e reiterar comportamentos próprios à menina e ao menino.

Poderíamos elencar uma série de exemplos de expressões e ações das crianças, nos cotidianos escolares, que reiteram "sentidos naturalizados sobre masculinidades e feminilidades" (Kaercher \& Dalla Zen 2010, 7) e que ora rompem com eles. É preciso suspender, na educação de crianças, algumas noções "normativas" que estas trazem "de casa", e outras que, algumas vezes sem perceber, outras deliberadamente, reafirmamos em nossas práticas pedagógicas, sobre as relações que atribuímos aos gêneros. Louro (apud Sostisso 2010, 9), afirma que "essas normas precisam ser constantemente citadas, reconhecidas em sua autoridade, para que possam exercer seus efeitos." A escola é uma das instituições que mais "citam", ou, nos dizeres de Louro, "reiteram" estas normas, em falas, ações e práticas pedagógicas as mais diversas.

Até agora, tratamos das relações entre os gêneros ligadas a concepções sobre as infâncias, movimento que tem sido notado em alguns contextos escolares. Docentes, no Brasil, tem aos poucos absorvido, timidamente, a ideia de que é preciso, o tempo todo, pôr em questão o que "é um/de menino" e o que "é uma/de menina". Contudo, há uma indefinição (ou seria uma definição que pretende excluir a criança) quanto às diversas formas de expressão e relação afetivo-sexual e das práticas sexuais entre as crianças. Movimento característico do dispositivo de sexualidade, que vem se desenvolvendo desde o século XVIII, em que

Na sexualidade da infância elabora-se a ideia de um sexo que está presente (em razão da anatomia) e ausente (do ponto de vista da fisiologia), presente também caso se considere sua atividade e deficiente se nos referirmos à sua finalidade reprodutora [...] sexualizando-se a infância, constituiu-se uma ideia de um sexo marcado pelo jogo essencial da presença e da ausência, do oculto e do manifesto (grifos meus). (Foucault 2012, 167) 
Sobre estes jogos de ocultação e manifestação da sexualidade nas infâncias, Felipe (2006, 204-205), em artigo que trata sobre a relação entre infância e pedofilia, adverte:

[...] se instalou uma intensa produção discursiva sobre a infância possibilitando, de certa forma, a veiculação de uma imagem infantilizada e dessexualizada das crianças, de modo que elas deveriam ser protegidas de determinados conhecimentos, com destaque especial para as questões referentes ao sexo e à sexualidade. Dessa forma, a infância tem sido acionada como uma espécie de espaço utópico, associada à inocência, ingenuidade, pureza, sensibilidade, desproteção, como um tempo de felicidade, onde reina o que há de mais puro e bom. A partir de tais concepções, a erótica infantil foi invisibilizada ou mesmo negada.

A autora também afirma que uma série de artefatos culturais, contraditoriamente a esta visão angélica da criança, estimulam a sexualidade infantil e a tornam objeto do desejo sexual adulto. Ela chama atenção para alguns artefatos da música como produtores de concepções de feminilidade e masculinidade, erotização, práticas sexuais (216-218). Em seguida, nos adverte sobre a estreita ligação entre infância e consumo, tratando da televisão, em que "as meninas, especialmente, procuram imitar mulheres adultas muito sensuais e, por vezes, os próprios apresentadores do programa se dirigem a elas de modo erotizado, mesmo sendo crianças" (220). A autora perpassa por diversas formas como as diversas mídias espetacularizam e estimulam a sexualidade infantil, ao mesmo tempo que negam sua legitimidade.

Inicialmente, poderíamos perguntar se, efetivamente, em algum período da história, as crianças estiveram tão preservadas assim de conhecimentos sobre as questões do sexo e suas práticas. Em seguida: tendo em vista as mudanças que o mundo digital, tecnológico e midiático vem trazendo na contemporaneidade e o boom da circulação de imagens, faz algum sentido conceber a criança como ser "fora do sexo"? O que ressalta, nos mais variados contextos escolares, são ações e discursos de interdição e repressores, toda vez que questões relacionadas às possíveis práticas sexuais infantis surgem. Porém, reafirmamos, se há múltiplas infâncias, há, também, múltiplas relações delas com o sexo e a sexualidade. Reprimir, supondo que a criança não deveria saber ou falar sobre sexo está ligado a uma produção de discursos e linguagens sobre as infâncias de caráter utópico, histórica, política e culturalmente demarcados, que nunca refletiram o que de fato ocorre com sujeitos desta faixa etária.

Afirmamos a necessidade de falar sobre sexo com crianças, principalmente, com o objetivo de proteção e preservação física, moral e psicológica. Utópico ou não, defendemos o "mundo sexual" das infâncias diferente do adulto. Àquelas crianças que conhecem um pênis ou uma vagina (que não a sua) e sabem das possíveis "utilidades" para estes órgãos; àquelas que sabem o que é um ato sexual, no ambiente familiar ou pelas diversas mídias; ou àquelas que são assediadas ou abusadas sexualmente, por exemplo, a escola não pode negar o direito de falar sobre sexo, ou de intervir, em casos que se faça necessário. É de extrema urgência, também, que as concepções sobre gênero — o que é "um/de menino" ou "uma/de menina"; como agem e "são" um homem e uma mulher — sejam postas em questão nas salas de aula.

Marília P. de Carvalho $(1999,32)$ nos chama a atenção para o "caráter 'adultocêntrico' da ciência ocidental [o qual a educação escolar reitera], em que a criança é sempre apreendida a partir do adulto, através do adulto ou como adulto que virá a ser". Enfim, teorias, legislações e os mais diversos dispositivos e artefatos culturais nos oferecem uma série de ideias que poderíamos operar com relação às possíveis infâncias (algumas infantilizando-as, outras adultificando-as). No trabalho docente, entramos constantemente em embate com manifes- 
tações as mais diversas no que diz respeito às possibilidades afetivo-sexuais, de expressão e identidade de gênero. Como propõe Foucault, os discursos sobre sexo e sexualidade são incitados o tempo todo, tenhamos consciência disto ou não. Urge que a instituição escolar e seus agentes reflitam acerca de concepções sobre as infâncias, deixando de lado a falácia de que estão frente a um "projeto de adulto" e encarem como são: cidadãos e cidadãs sexualizados e generificados, cada qual habitando a sua infância. Só assim qualquer projeto de educação para a sexualidade poderá ser realizado em direção da superação de uma série de hipocrisias e "repressões", reafirmados no cotidiano escolar, vistos como "naturais", essenciais às crianças, que não cabem mais no mundo digital, tecnológico e midiático que põe o sexo à mostra para todos, nem nas propostas mais contemporâneas com relação à educação sexual. Só assim, poderemos discutir e incluir, no Ensino de Artes Visuais para crianças, determinadas categorias do campo da Arte, em relação com uma série de outras categorias, dentre elas, gênero e sexualidade.

\section{"PEDAGOGIAS DO FEMININO" E “PEDAGOGIAS DA SEXUALIDADE" NO ENSINO DE ARTES VISUAIS}

Nosso primeiro recorte, "emprestado" de Loponte (2002, 283-284), diz respeito ao papel atribuído à mulher no decorrer da História da Arte $^{2}$ - seja como objeto de contemplação, especialmente nas produções de nus femininos; seja de mulheres artistas, em suas produções e nas possibilidades dadas a elas de circulação nas instituições artísticas. Segundo a autora:

Fazendo um contraponto entre as obras de mulheres e homens artistas de diversos períodos, discuto como a sexualidade feminina é colocada em discurso através dessas imagens, produzindo uma pedagogia do feminino. Uma pedagogia visual que naturaliza e legitima o corpo feminino como objeto de contemplação, tornando esse modo de ver particular como a única 'verdade' possível.

Abordando autoras que produziram trabalhos refletindo sobre a relação feminino-Arte, Loponte analisa discursos que são "uma interpretação pertencente a um sistema de significações muito particular, no qual um certo olhar masculino é dominante" (285). Corrobora conosco sobre a necessidade de desnaturalizar este campo, de analisá-lo como uma produção constante e marcada por determinados imperativos culturais e reflete o quanto as imagens formam estudantes e docentes, dentro e fora das salas de aula. Trazendo os estudos de gênero como categoria de análise, Loponte $(2002,286)$ nos diz que "a chamada 'história universal da arte' é uma história particular, que sistematicamente vem privilegiando um determinado modo de ver como o único possível." Propõe a análise de temas muito caros a artistas de determinados períodos da História da Arte ocidental, geralmente de origem religiosa (bíblica) ou mitológica, como O Julgamento de Páris, As Filhas de Leucipo, Olympia, As Três Graças, O Rapto das Sabinas e Susana e os Velhos, e nos mostra o lugar do feminino nestas obras, propondo, por exemplo, que estes "são a desculpa, e não o tema. O tema é o próprio nu feminino" (286); ou "é a sexualidade da mulher que está sempre em constituição, ela é a categoria vazia. Apenas a mulher parece ter 'gênero'" (286), referindo-se a Laqueur; ou que "na realidade, nas representações de nus femininos é a sexualidade masculina que está em jogo, tendo muito pouco a ver com a própria sexualidade feminina" (Loponte 2002, 287). 
No mesmo artigo e em outros trabalhos, Loponte analisa formas como o feminino é retratado por artistas modernos, aí já deslocados de temas canônicos, mas que ainda conservam este olhar masculino no qual o feminino é dominado, objetificado, determinado. Este tipo de análise proposto por Loponte está presente nas aulas de Artes Visuais? As formações de professoras e professores de Artes Visuais abarcam questões como estas? Tendo em vista que obras como as citadas são comumente expostas e estudadas em escolas e universidades, temos questionado como elas nos formam, nos constituem? Loponte $(2002,287)$, a seguir, nos fala sobre os lugares reservados a elas:

As mulheres que ousavam entrar no mundo artístico tinham que se contentar com a representação de pinturas de interiores, naturezas-mortas - gêneros de menor valor no mercado artístico e que não as fariam configurar no rol dos 'grandes artistas'. Às mulheres era vedado o acesso à prática de desenho do natural com modelo nu, que foi a base do ensino acadêmico e da representação na Europa do século XVI ao XIX. As mulheres 'artísticas' por natureza deveriam ser controladas de alguma forma, sendo proibidas de estudar arte fora do contexto estético doméstico (decoração de interiores, arranjos florais, tocar piano etc.). Quando historiadores e críticos de arte referem-se às mulheres artistas, a alusão a sua sexualidade parece algo inevitável, interferindo no julgamento das obras. É preciso lembrar sempre que, antes de artistas, elas são mulheres.

Que mulheres artistas conhecemos nas primeiras fases de da constituição deste campo da Arte - do século XV ao XIX, por exemplo? Ao tratar da arte moderna, que celebrava, grosso modo, a criação e a novidade em contraposição às tradições artísticas tão caras até o século XIX, Loponte traz Griselda Pollock, que analisa os espaços da feminilidade neste contexto. As autoras reafirmam, neste período, um olhar masculino que constrói nossa concepção sobre o que é "A Arte",

[...] um olhar que, congelado na definição de 'arte universal', subjetiva e molda nossas concepções do que é arte e artista, e, na análise que procuramos fazer aqui, 'inventa' sexualidades, feminidades e também masculinidades. (289)

Se, por um lado, na arte moderna "as representações de corpos femininos, como signos da sexualidade masculina, afirmavam a modernidade dos homens artistas e sua posição de vanguarda" (288); por outro, é neste período que mulheres artistas começam a ter acesso às formações oficiais, em academias de belas artes, ou a participar ativamente dos movimentos artísticos de vanguarda, por exemplo; além de apresentar mais ativamente, em seus trabalhos, visões do feminino que se afastam daquelas que o submetem ao masculino, que o objetificam. Pela primeira vez, um número maior de mulheres passa a veicular, em suas obras, olhares sobre o feminino que "falam de si." Um silêncio (ou um silenciamento, ou seja, uma ação de silenciar que parte de outro lugar, em uma relação desigual de poder) de cinco séculos começava a ser quebrado.

Este artigo não é um trabalho do campo da História da Arte, contudo, compreendendo que este não é "neutro", nem universal, que é construído como qualquer outro e, também, que é feito a posteriori, lançamos, aqui, algumas questões: Como as mulheres artistas participaram desta "novidade" que é a arte moderna? Como propuseram outros olhares sobre a feminilidade? Como se apropriaram de questões essencializadas do feminino para agir no campo artístico? Que lugares tiveram dentro dos movimentos artísticos de vanguarda? 
Como a História da Arte vem lendo as obras destas mulheres no decorrer do século XX e início do XXI? Enfim, como, pouco a pouco, foram transformando o lugar da mulher artista no campo da produção e circulação artística? E: como produzir uma História da Arte que articule os estudos de gênero como categoria de análise? Obviamente que não responderemos estas perguntas aqui, entretanto, consideramos extremamente necessárias para o Ensino de Artes Visuais e afirmamos que não é possível tratar das questões de gênero sem ter estas e outras perguntas à vista.

Nossa opção por Loponte foi realizada tendo em vista, principalmente, sua articulação dos estudos de gênero com o campo da Educação e com o Ensino de Artes Visuais; o combate a visões formalistas; a preocupação com os estudos de gênero como categoria analítica; o foco nas imagens enquanto formadoras, constituintes, construtoras de conceitos e identidades; dentre outros motivos que podem ser entrevistos aqui. A autora, também, nos ajuda a propor e a responder algumas das questões que colocamos acima. Como propõe Judith Butler (2015), gênero não é sinônimo de feminino. Assumimos o mesmo recorte proposto por Loponte por compreendermos a contingência da relação feminilidade-Arte contemporaneamente, além de uma produção bibliográfica já consolidada na articulação com o campo da Arte. Contudo, há que se pensar: Como implicar as masculinidades nos estudos de gênero, dentro do Ensino de Artes Visuais? E questões como transexualidade, travestilidade, transgeneiredade? O que fazer quando gênero e sexualidade "se amalgamam"?

Em muitos de seus trabalhos, Louro nos fala sobre a aproximação destas duas categorias de análise: gênero e sexualidade, que aparecem "fundidas" em partes deste trabalho, assim como ocorre em políticas públicas e no cotidiano escolar. Cabe apontar que, nos próprios movimentos sociais ligados às questões abordadas, estas articulações são importantes, como ocorre com travestis, transexuais e transgêneros, por exemplo, dentro do movimento gay, em determinados contextos históricos e locais; e que, é no sujeito que estas articulações se materializam, cada pessoa apontando para uma categoria e/ou para outra, em maiores ou menores graus, identificando-se ou não com elas. Todavia, com intuito didático, nesta seção, operamos uma distinção gênero - sexualidade. A partir de agora, trazemos as discussões sobre possibilidades afetivo-sexuais, conforme nos propõe Araújo \& Santos (2009).

Para esta discussão, abordamos o autor Belidson Dias, que tem discutido o lugar das questões de gênero e sexualidade no Ensino de Artes Visuais. Se, no campo da produção artística, artistas têm produzido trabalhos e poéticas em que questões da sexualidade são centrais em suas linguagens, no campo de seu ensino, estas questões parecem não importar:

As práticas cotidianas da arte/educação contemporânea no Ensino Fundamental, Médio e

Superior, no Brasil, são marcadas pela negligência com a experiência cultural do cinema,

o descaso com questões de gênero, assim como a ocultação e dissimulação do assunto

"sexualidade". (Dias 2006, 102)

Aqui voltamos o foco para algo que nos parece importante: as condições identitárias do sujeito que produz e é produzido pela obra de arte, pela crítica e pela história deste campo. Loponte e seus referenciais tratam diretamente dos sujeitos/conceitos "mulher" e "feminino" no contexto da História da Arte. Para políticas afirmativas, "negro/negra", "indígena", por exemplo, precisam ser conceituados, constituídos enquanto sujeitos de direito. Parece muito mais difícil tratar dos sujeitos/conceitos ligados à sexualidade, especialmente na Educação. Com relação à História da Arte e procurando perfazer o mesmo caminho de Loponte, podemos lançar algumas 
questões: Que lugares LGBTTTQIA ${ }^{3}$ tiveram como produtores e produtoras de Arte no decorrer da constituição deste campo - a Arte? Como foram retratados e retratadas? É importante saber da orientação sexual de determinada/o artista? Que consequências a resposta a esta última questão podem ter com relação à "ocultação e dissimulação" da qual Dias nos fala?

O autor nos traz, também, a questão da "moralidade cultural":

Um assunto muito importante para a teoria e a prática da arte/educação. Sem dúvidas, a análise de representações de gênero e sexualidade normativas e não-normativas (queer), projeta reflexões sobre o impacto teórico e prático que a compreensão destes sistemas visuais e seus discursos teriam na educação da cultura visual. (Dias 2006, 114)

Não é difícil, no cotidiano escolar, vermos discussões acerca da sexualidade serem evitadas, tendo em vista certas noções de "moralidade." No contexto desta pesquisa - as infâncias - é ainda mais complicado, já que, em termos gerais, a criança estaria "fora do sexo". Contudo, questionamos: entender este ser em formação - a criança — como um não-praticante do ato sexual requer que ele/ela não saiba das possibilidades afetivo-sexuais que poderá exercitar? Se separarmos afetividade e sexo: a criança não pode realizar seus jogos afetivos além das possibilidades heteronormativas? Apenas na adolescência a criança deve se deparar com o que está fora da norma? O que fazer, por exemplo, com crianças que vivem em famílias em que há uniões homoafetivas?

Junto à moralidade, Dias $(2006,120)$ nos coloca a prática da censura:

Não obstante a estrutura de poder, a censura tem uma história longa na arte/educação. As instituições da arte/educação escondem, estrategicamente, os gêneros, mas invariavelmente, silenciam a sexualidade. A arte/educação permeada pela censura, agora e num passado próximo, exclui as representações de gêneros que incomodam as regras da normalidade, assim como aquelas que mostram preferências sexuais diferentes.

Assim como Loponte e Louro, Dias nos coloca frente a reflexões de como conhecimentos são "selecionados", tornados importantes, ou não, de serem ensinados nas escolas, tendo em vista estas noções de moralidade, censura e tantas outras que perpassam a construção dos campos da Arte, da Educação, da História da Arte e do Ensino de Artes Visuais. Loponte e Dias lançam olhares para algumas "posturas pedagógicas" (práticas, seleções, metodologias, construções curriculares) que tem sido vistas como estáveis no campo da Arte, de sua história e de seu ensino e que nos impedem de tratar de gênero e sexualidade na escola. Posturas estas que, geralmente, excluem as sexualidades não-normativas da educação formal. Há fronteiras no campo do Ensino de Artes Visuais que precisam ser visitadas (e atravessadas), conforme afirma Louro (2015). Loponte, Dias, dentre tantos autores e autoras do campo do Ensino de Artes Visuais nos ajudam a identificar um destes lugares estáveis para os currículos de Arte — o formalismo; objeto da nossa próxima seção. 


\section{PADRÕES DE ESTABILIDADE: O FORMALISMO NO ENSINO DE ARTES VISUAIS}

É importante desconstruir o processo de fabricação do currículo, de forma a mostrar as opções e os interesses que estão subjacentes a uma determinada configuração do plano de estudos e das disciplinas escolares [...] é preciso sublinhar a dimensão social, uma vez que o currículo está concebido para ter efeito sobre as pessoas, produzindo processos de seleção, de inclusão/exclusão e de legitimação de certos grupos e ideias (Goodson 1997, 10).

No trecho acima, Ivor Goodson, pesquisador do campo do currículo inglês, coloca-o em contextos históricos; como temos afirmado com relação a outros campos de conhecimento. Em análises centradas na sociologia do conhecimento escolar, nos traz o conceito de disciplinas escolares e "aborda o papel dos diversos grupos sociais na definição conflitual do currículo" (11). O autor afirma que, nas diversas construções curriculares, seja nas matrizes (distribuição de cargas horárias para cada disciplina), seja nos conhecimentos internos a cada disciplina, "o sistema foi concebido para assegurar a estabilidade e para dissimular as relações de poder que sustentam o conjunto de ações curriculares" (Goodson 1997, 11).

Nosso interesse por Goodson vem, principalmente, por sua proposição de que há padrões de estabilidade (e padrões de mudança) nos currículos. Esta discussão nos parece bastante próxima do que a teoria queer, por exemplo, nos propõe, quando chama à visita às fronteiras, à desestabilização, ao movimento de conceitos e noções que temos como caros nos programas de cada disciplina e que formam sujeitos. No caso específico das Artes Visuais, uma das questões é a presença maciça do formalismo enquanto estruturante dos programas, e, portanto, da noção que eles veiculam de/sobre Arte. Como propõe Dias $(2006,105)$ :

\footnotetext{
Atualmente, as escolas de arte e cursos de licenciatura em arte/educação têm que enfrentar a necessidade social de desafiar as noções predominantemente formalistas dos seus currículos e começar a explorar intensamente as experiências do cotidiano, dos sujeitos, suas trocas materiais e sensoriais. É, pois, dessa perspectiva que os arte/educadores são chamados a discutir e entender porque, historicamente, o currículo de arte/educação em geral tem valorizado, sobretudo, a produção e apreciação artística das Belas Artes, em vez de buscar a compreensão crítica da representação da visualidade na sociedade.
}

Goodson, em seu trabalho, nos fala de processos históricos, na realidade inglesa, em que disciplinas ganharam e perderam espaços nos currículos daquele país. Ele afirma que "a história das disciplinas escolares deve ser contada como a história das forças sociais que as trouxeram para os currículos" (Goodson 1997, 12). Durante o processo de construção desta pesquisa, a disciplina de Arte sofreu uma série de ameaças, junto à Sociologia, à Filosofia e à Educação Física, especialmente no Ensino Médio. ${ }^{4}$ Os atores sociais, as instituições e as instâncias de poder que agiram, diga-se, o Governo Federal apoiado por uma série de organizações da sociedade civil, propuseram não somente a exclusão de disciplinas, o aumento de cargas horárias de outras, mas, também, questões internas às disciplinas - seus conteúdos, metodologias. Na história da disciplina de Arte, na educação brasileira, muitas foram as estratégias para justificar sua presença nas grades das diversas redes.

Contudo, o que nos interessa tratar aqui, são as modificações no interior da disciplina Arte. Como determinadas formas de estruturar o Ensino de Artes Visuais têm sido vistas como "estáveis", ao ponto de docentes da área, programas de formação de professores e professoras, 
além de organizações curriculares refletirem, sem questionamentos, estas formas? Ana Mae Barbosa (2012b, 2012c) nos fala como determinadas maneiras de se conceber o Ensino de Artes Visuais foram hegemônicas em certos momentos, no Brasil, em toda a sua recente história; localizando estes movimentos de mudanças nas arenas de disputa social, trazendo os "atores" e "atrizes" destas redefinições da área. Ela também nos mostra, em diversas de suas obras, como, nacional e internacionalmente, no decorrer do século XX, docentes de Arte (nas escolas, na educação não-formal e na academia) foram procurando criar vocabulários, terminologias, metodologias, compreender especificidades da disciplina Arte, na educação formal e fora dela.

Em finais do século XX, no Brasil, docentes da área começam a exercitar determinadas maneiras de conceber seu ensino, e o formalismo passa a ser um dos principais estruturantes, organizadores dos conhecimentos que serão oferecidos a estudantes nos diversos níveis de ensino, especialmente nos Anos Iniciais do Ensino Fundamental. Outro exemplo pode ser visto na estruturação em um viés histórico-linear da História da Arte, no geral, privilegiando uma determinada visão, eurocêntrica e norte-americana, da Arte. Ou, o que é mais comum, a estruturação curricular-programática ocorre no entrecruzamento entre elementos formais + História da Arte (juntos do fazer e da composição, que, muitas vezes, são subentendidos).

São questões e terminologias caras à Arte, sua história e seu ensino, contudo, é necessário que se alarguem as noções e conceitos que estruturam propostas curriculares para as Artes Visuais. É preciso "visitar as fronteiras", explorar aqueles territórios em que "a Arte já não é apenas Arte." Expliquemo-nos: não se trata de encontrar formas de a Arte auxiliar no ensino de outras disciplinas, mas deslocar-se para pontos em que as obras, objetos e ações artísticas exploram outras instâncias da vida social, outras disciplinas, discursos e enunciações. E por um motivo muito simples: os componentes sociais, filosóficos, históricos, sociológicos, psicológicos, identitários; fazem parte da estrutura, do "ser" das obras e objetos de arte; das relações que elas mesmas, e artistas que as produziram, propõem com o mundo; dos significados que cada sujeito pode dar às obras, em contextos históricos e locais variados. Todas estas questões têm relação direta com nossas percepções e exercícios de gênero e sexualidade, dentre outras categorias, nos currículos, como Loponte $(2008,155)$ nos fala:

Há, sim, uma rede de discursos, um jogo discursivo atuante que alia gênero [sexualidade], arte e poder, que produz efeitos em nossas práticas e em nossos modos de ver e que tem sistematicamente desfavorecido as mulheres [homossexuais, bissexuais, transexuais]. Leituras de imagem que levem em conta análises mais políticas, como as de Linda Nochlin e/ou a análise de discurso de Foucault contribuem para o rompimento de um discurso quase "religioso" que gira em torno da arte, colocando-a no reino intocável e transcendente da sensibilidade, acima de qualquer questão política. Há mais na superfície das imagens para analisar do que supõem as leituras de imagem formalistas mais comuns. Além dos elementos visuais e das nossas interpretações acerca do que o artista "quis dizer", podemos considerar as produções artísticas como modalidades enunciativas que, na trama dos discursos que circulam em torno delas, colaboram para fixar e produzir identidades sexuais, femininas e masculinas.

Portanto, não é possível falar de Arte sem tratar de seu contexto e, principalmente, é urgente que o Ensino de Artes Visuais passe a ampliar o campo das manifestações que apresenta como pertencentes a este campo a que chamamos Arte. Ivone M. Richter (2000, 11), ao tratar sobre preconceitos muito recorrentes contra as culturas populares e o artesanato, por exemplo, afirma que 
[...] a tendência no ensino das artes visuais, ainda hoje, é reproduzir conceitos modernistas de arte largamente aceitos nos meios acadêmicos. Este enfoque exclui todas as artes chamadas 'menores', e com a exclusão delas, toda a possibilidade de um trabalho intercultural em arte.

A autora aponta para o fato de que estas, muitas vezes, são vistas como formas menores por terem "menos elaboração", o que nos levaria a pensar, ainda, na Arte como originalidade, um conceito calcado no modernismo das vanguardas do início do século XX. Corroborando com as propostas de Richter, afirmamos que os embates arte-artesanato; popular-erudito, dentre outros; precisam ser "suspensos", "borrados" se pensamos em um Ensino de Artes Visuais que se aproxime das questões que tratamos neste trabalho (da articulação gênero-sexualidade-Arte). O próprio debate se estas manifestações são, ou não, Arte, devem ser parte das aulas de Artes Visuais, desde a escolarização das crianças mais pequenas.

Ao revisar as produções que articulam o Ensino de Artes Visuais às questões de gênero e sexualidade ${ }^{5}$, percebemos a força do formalismo enquanto elemento de estabilidade. Um programa de Artes Visuais para os Anos Iniciais do Ensino Fundamental, aparentemente, navega em mares confortáveis quando baseado em "elementos da linguagem visual". Quando analisamos planos de curso para os Anos Iniciais do Ensino Fundamental pudemos perceber como estes estáveis elementos estruturam os programas; junto a outras ideias sobre Arte, sua história e seu ensino que dificultam sobremaneira um mergulho em questões outras que as obras, objetos e ações, principalmente as contemporâneas, nos propõem. Loponte (2008, 156) nos fala das constantes reiterações realizadas nas aulas de Arte:

\footnotetext{
As imagens dizem muito, nos produzem, nos significam, nos sonham. Na escola, as aulas de arte, bem ou mal, têm sido o espaço (às vezes, o único) de produção e leitura de imagens. Mas há que se perguntar se há algum espaço para leituras menos formalistas [...] Na Educação Infantil e nos Anos Iniciais do Ensino Fundamental, as imagens femininas estereotipadas povoam cartilhas, livros didáticos e as "inocentes" decorações escolares. Como professoras educam e reforçam uma determinada "pedagogia visual do feminino" ? E, por outro lado, como elas próprias são educadas através das imagens de mulheres? Na história da arte ocidental, muitas das obras, consideradas marcos nos seus respectivos períodos artísticos, celebram e legitimam um olhar masculino sobre a imagem de mulheres. Estas obras, embora façam parte de uma iconografia chamada "universal", constituem representações de um determinado modo de ver muito particular, sistematicamente privilegiado como o único possível.
}

\section{CURRÍCULOS FORMALISTAS PARA AS INFÂNCIAS}

Por uma série de motivos, evidenciados na pesquisa de Mestrado, optamos por analisar programas de três escolas "de referência" da cidade do Rio de Janeiro: CAp/UERJ — Colégio de Aplicação da Universidade Estadual do Rio de Janeiro; CAp/UFRJ — Colégio de Aplicação da Universidade Federal do Rio de Janeiro; e Colégio Pedro II (CPII).

A análise é bastante exaustiva, por isso, pontuaremos, mais abaixo, alguns achados desta pesquisa, em relação direta com estes "elementos de estabilidade" abordados anteriormente. Cabe ressaltar que nenhum dos documentos abarca diretamente aos temas principais desta pesquisa - as questões de gênero e sexualidade nos currículos de Artes Visuais. São, portanto, categorias completamente invisibilizadas. Por isso, nos interessamos pela intersecção proposta por Bell Hooks $(2013,41)$ que traz à discussão o "feminismo das mulheres negras 
e de cor" e vem articular mais duas categorias a essas discussões — raça e classe social: “juntei à luta pelo fim do racismo um compromisso com o fim do sexismo e da opressão sexista e com a erradicação dos sistemas de exploração de classe". Ativa no movimento e na teoria feminista e, ao mesmo tempo, nos da negritude norte-americana, desde a década de 1970, nos conta de suas dificuldades para circular nos dois movimentos. No primeiro, era-lhe negado falar de racismo e incluir a experiência dos homens negros, além da rasa concepção de que as mulheres negras já eram "libertas" por trabalharem fora, sem que se levasse em consideração os tipos de trabalho e de dominação ao qual estavam sujeitas as mulheres negras, inclusive e principalmente "pela mão" das mulheres brancas; criticadas pelos teóricos homens ligados à negritude.

A Hooks (2013) unimos Butler (2015), Foucault (2012), Louro (2015) e Munanga 2015), para "explorar fronteiras" e afirmamos a necessidade de agir a partir da "solidariedade" — a articulação de categorias de análise, de dimensões dos sujeitos. Num primeiro momento, estas fronteiras se concretizam em cada pessoa que transita entre "ser/estar" em condições humanas variadas. Nesta perspectiva, o sujeito deve ser "solidário consigo mesmo"; os jogos de poder são únicos e subjetivos: a consciência de ser "uma mulher" ou "uma negra", em Hooks, por exemplo, trazem problemas que emergem em maior ou menor grau, em contextos e tempos variados. Num segundo momento, as identidades banham as relações sociais mais próximas e não podem ser ignoradas pela escola.

Uma série de dinâmicas sociais ocorridas nos últimos tempos tem trazido à tona as discussões sobre gênero e sexualidade em termos bem diferentes de outros momentos históricos, exigindo a elaboração de estratégias nas práticas educativas e nos currículos. Contudo, no decorrer da pesquisa, percebemos que não haveria formas de tratar de gênero e sexualidade sem se aproximar de outras questões mais consolidadas nos currículos de Ensino de Artes Visuais e em formações docentes. Partimos da premissa de que não há como discutir gênero e sexualidade nos currículos sem ser solidário às questões de raça, etnia ${ }^{6}$, classe, dentre outras; e a análise dos documentos, aqui, será permeada por estas categorias. Portanto, currículos que não abordam questões relativas às culturas africanas, afro-brasileiras e indígenas (como propõe as leis afirmativas 10.639/03 e 11.645/08) e relações com as culturas populares e regionais (como propõe os PCNs-Arte) ou com o multiculturalismo/interculturalidade (já bastante disseminados nas formações de docentes de Arte, pelo menos, desde a década de 1990 (Richter, 2000)), dificilmente "chegarão" às questões de gênero e sexualidade.

1. CAp/UERJ: das três instituições, é a que apresenta o programa mais calcado nos "elementos da linguagem visual"7. Não apresenta nenhuma reação às leis afirmativas sobre Cultura e História africanas, afro-brasileiras e indígenas, nem referenciais do campo da História da Arte, por exemplo, que possam auxiliar numa análise sobre que Arte é apresentada a estudantes. Dentre os referenciais de Ensino de Arte, não vemos nenhum título relativo às pesquisas sobre multi/interculturalidade. Enfim, este programa é estruturado sob uma base estritamente formalista;

2. CAp/UFRJ: este documento, mais extenso, é organizado tendo em vista uma "compreensão conceitual dos elementos fundamentais das Artes Visuais e sua presença na História da Arte"8, ou seja, sua estrutura é guiada por um caráter formalista/historicista ${ }^{9}$. Apresenta referenciais mais abrangentes e uma reação às leis afirmativas relativas às categorias etnia (11.645/08) e raça (10.639/03) em conteúdos do $3^{\circ}$ Ano do Ensino Fundamental: "Apresentação, observação e análise de expressões artísticas de origens e períodos variados: indígena, 
africana, brasileira e europeia". Nossa crítica repousa no fato de que, mesmo tratando de uma "inclusão", sugere uma abordagem "comparativa" entre as variadas culturas. A norma não precisa ser citada, já que está implícita. No caso da arte ocidental, a europeia é a norma. É através de um olhar europeu que compreendemos o conceito e "selecionamos" os objetos que são considerados "arte". Conforme nos propõe Louro $(2011,65)$ :

A atribuição desse qualificativo - diferente - supõe, sempre, alguma espécie de comparação. Mesmo que não se mencione explicitamente, quando dizemos que alguém ou algo é diferente temos uma referência, estamos fazendo uma atribuição, uma nomeação que supõe um lugar que não é diferente, uma posição ou um lugar que seria o não-marcado, o "normal." Na perspectiva teórica que trabalho, entendemos a diferença não como um "dado" que preexiste nos corpos dos sujeitos para ser, simplesmente, reconhecido; mas, em vez disso, assumimos que a diferença é sempre atribuída e nomeada no interior de uma determinada cultura.

E, é claro, ela é atribuída a partir de uma posição que se toma como referência.

O documento não marca racial, étnica ou regionalmente a arte em nenhum outro conteúdo. Portanto, é de uma arte eurocêntrica que está tratando, o tempo todo. No contexto em que vivemos, sabemos que determinadas manifestações só serão abordadas se forem devidamente "marcadas" no currículo, por isso existem as políticas afirmativas; daí a importância de leis como a 10.639/03 e a 11.645/08. Podemos supor, inclusive, que este conteúdo é uma reação a estas leis. Logo, questionamos: Por que as origens europeias, que são normativas no contexto da arte ocidental, aparecem neste conteúdo? Este documento, também, é o que mais releva a importância dos principais sujeitos do processo educacional: docentes e estudantes. Elementos trazidos por alunos e alunas são essenciais para os processos propostos no Ensino de Artes Visuais desta instituição. Hooks (2013) nos fala, diversas vezes, que questões relacionadas a gênero, classe e raça, dentre outros, serão explorados com muito mais frequência e maior qualidade, se emergem de problemas próprios daquela "comunidade de aprendizagem".

1. CPII: dos documentos analisados, é o único que não apresenta uma estrutura guiada por elementos formais das Artes Visuais; mesmo que os "elementos da visualidade"10 perpassem e organizem todo o programa e sejam foco principal no $4^{\circ}$ Ano. Em cada trimestre, apresenta um Eixo Temático, a ver: $1^{\circ}$ Ano: Arte e Corpo; Arte e Infância; Arte e Paisagem; $2^{\circ}$ Ano: Arte e Natureza; Arte Indígena; Arte Popular; $3^{\circ}$ Ano: Arte e Ancestralidade; Arte e Mitologia; Arte Afro-brasileira; $4^{\circ}$ Ano: Arte e Representação - Pintura; Arte e Representação Escultura; Arte e Representação - Arquitetura; 5 Ano: Linguagem Fotográfica; Mídias Contemporâneas; O Trabalho do Artista na Contemporaneidade. Como se pode vislumbrar, este programa "marca" momentos para se estudar questões relativas leis afirmativas às culturas e histórias africanas e afro-brasileiras (no $3^{\circ}$ Ano, relação com a 10.639/03) e indígenas (no $2^{\circ}$ Ano, 11.645/08); além de se comprometer a tratar da relação arte-artesanato-cultura popular, também no $2^{\circ}$ Ano. Focaremos nossa análise nos $2^{\circ}$ e $3^{\circ}$ anos.

$2^{\circ}$ Ano: o segundo trimestre trata diretamente de uma questão étnica - Arte Indígena. Aparecem, nos eixos temáticos: "Identidade e valores culturais" e "A presença da cultura indígena no mundo contemporâneo". Noções como "valor" e "presença", da forma como estão colocadas, insinuam uma hierarquização, na qual o que é indígena está abaixo. E por quê? Porque a "presença" e o "valor" do que é normativo (neste caso, o europeu, o ocidental "do 
norte") não precisam ser marcadas. A "arte canônica ocidental" (Loponte 2002) está presente e tem seu valor por si. O diferente, o indígena, precisa ser encontrado e "valorizado" para se tornar inteligível. Compreendemos que estes ainda são termos-noções-conceitos a serem elaborados e que políticas de afirmação constroem categorias, estratégias teóricas e práticas pedagógicas em processo.

No terceiro trimestre temos Arte Popular. Há apenas um eixo - "Artistas populares e suas poéticas". Perguntamos: O que define um artista como popular? O que o documento está chamando de "poética"? O que dizer de artistas populares que repetem formas — os chamados artesãos e artesãs? Como acionar o conceito de "poética" neste contexto? A "arte popular" precisa do conceito de "poética" ? Não seriam necessárias outras, ou "novas" categorias teóricas para este terreno que liga a arte ao popular? Enfim, compreendemos, mais uma vez, que o documento realiza, aqui, uma importante ação de inclusão de manifestações artísticas; contudo, novamente, realiza um processo de hierarquização. No campo da Arte, no Brasil, diversos artistas, autodidatas ou aprendizes de formas culturais populares tradicionais, vem sendo reconhecidos como "artistas", no geral porque trazem "inovações", "autenticidade" nas suas formas de abordar o que aprenderam ${ }^{11}$. Neste caso, a ligação entre arte popular e poética são evidentes. Mas, o que dizer, das formas do artesanato, ou seja, aquelas que se repetem?

Como o programa não visibiliza o termo "artesanato", como faz Richter (2000), não podemos afirmar se o mesmo, com todas as possibilidades de variação no território nacional e fora dele, é abordado aqui. Dos objetivos ressaltamos: "Estabelecer diálogos entre artistas populares e eruditos". Aqui, o documento afirma estas categorias - popular e erudito - como separadas, sem hierarquizá-las. Nos faltam subsídios para compreender o que "está no meio do caminho", ou seja, toda a gama que vai do popular ao erudito, bem como aquelas figuras que transitam entre estes terrenos. Enfim, perguntamos: Há fronteira entre o popular e o erudito?

$3^{\circ}$ Ano: o programa é organizado de forma multi/intercultural, tanto que, no segundo trimestre, os eixos são: Multiculturalismo e Interculturalidade. No $1^{\circ}$ Trimestre, no eixo Ancestralidade sugere-se a possibilidade de discutir questões relativas a etnias e raças, a possíveis formações culturais do "povo brasileiro". O conceito de identidade figura aqui, evidenciando a pesquisa por elementos da identidade de estudantes, em comunicação com seus "valores ancestrais".

Se o documento fosse datado, poderíamos dizer que Arte Afro-brasileira é uma reação à 10.639/03. O primeiro dos três eixos é "Manifestações culturais pelo Brasil afora". Aqui percebemos uma dinâmica bastante comum: ligar o termo "cultura" a manifestações geralmente subalternizadas. Tanto que, nos programas dos $4^{\circ}$ e $5^{\circ} \mathrm{Ano}$, mais formalistas e ligados a visões mais normativas da "Arte", o termo "cultura" não aparece nenhuma vez. Nos ateremos a fazer algumas questões: De que "manifestações culturais" o documento está tratando? Por que tratar de "manifestações culturais" como eixo temático apenas ao abordar a arte afro-brasileira?

Nos conteúdos, mais uma vez, as ideias de "valor" e "presença" (implícita no verbo "identificar") ocorrem; desta vez, ligadas ao ato de "respeitar". Enfim, mais uma vez afirmamos a necessidade de programas curriculares construírem caminhos. Não defendemos "fórmulas eficientes" para a Educação Básica, contudo, não é de se negar que alguns conteúdos, de tão exercitados, reiterados, passam a ser facilmente oferecidos, sem tantos "senões". Não é o mesmo com as questões africanas e afro-brasileiras, elas só estão nos currículos de Arte porque respondem a uma ação afirmativa curricular: a 10.639/03. Portanto, celebramos a atitude presente neste plano de curso, ansiando para que o mesmo possa vir a ocorrer com relação às questões de gênero e diversidade sexual, preferencialmente, em um futuro próximo. 
Enfim, na década de 1990, nos PCNs para os Temas Transversais — Orientação Sexual (Brasil, 1998) e, posteriormente, com outras publicações oficiais, questões relativas a gênero e sexualidade foram colocadas para a Educação, contudo, sem "a força de lei" empreendidas com as categorias raça e etnia, por exemplo. Não são abundantes, ainda, as pesquisas que tratam da intersecção gênero-sexualidade-Ensino de Artes Visuais, especialmente quando falamos da Educação Básica. Ao procurarmos estabelecer relações disto tudo com o currículo e quando focamos nas infâncias; vislumbramos uma completa escassez de trabalhos. Ressaltamos, nos trechos analisados dos documentos, a naturalização e a essencialização do formalismo como "conteúdo básico" para os Anos Iniciais do Ensino Fundamental, e maneiras como determinadas palavras corroboram para a invisibilização e o silenciamento de uma gama enorme de sujeitos envolvidos com as categorias que buscamos aproximar — gênero, sexualidade, raça, etnia e classe social — às quais poderíamos somar um sem-número de outras. E afirmamos: diferente do que estes documentos mostram, as categorias gênero e sexualidade devem estar explícitas em seus "desenhos", ser marcadas; além de, como propunham os PCNs, atravessar todo o seu contorno, todos os seus "conteúdos".

\section{CONSIDERAÇÕES FINAIS}

Talvez a escola, instituição disciplinar por excelência (Foucault 1987) onde estratégias normatizadoras e transgressoras se encontram e entram em conflito, seja o lugar privilegiado para tratarmos das questões implicadas nesta pesquisa (Hooks 2013). De tempos em tempos, e em sociedades e países distintos, a escola ganha destaque na arena de disputas dos campos político e social. Nestes contextos, o que ensinar, como ensinar, por quê ensinar, para quem ensinar e tantas outras questões "educacionais" ganham visibilidade e os sujeitos implicados nestes processos "aparecem". Se nosso foco se dirigir à escola pública, espaço democrático por definição, onde, teoricamente, todos os grupos, todas as diferenças se encontram e entram em conflito, este cenário se apresenta ainda mais complexo; a "fronteira" entre a norma e a transgressão se tornam ainda mais tênues. O ofício de educar ocorre, sempre, "no fio da navalha"; em pontos nos quais paradigmas se confrontam.

Os documentos analisados nesta pesquisa nos revelam, em maior ou menor grau, diversos destes embates, no campo do Ensino de Artes Visuais; e na sua relação com outros campos e categorias do conhecimento. Mesmo a busca por estabilidade, traduzida, aqui, pelo formalismo nas Artes Visuais, não deve ser minimizada como estratégia, que pode conter, em si, objetivos os mais diversos, e que não se reduzem a normatizações e reiterações. No caso do Ensino de Arte, ${ }^{12}$ área do conhecimento subalternizada nos mais variados contextos escolares (Nogueira 2008), o anseio pela estabilidade tem a ver com lutas de manutenção da área e inteligibilidade, por exemplo. Entretanto, qualquer estabilidade será sempre sensível e, o que esta pesquisa traz, em contextos históricos e locais "de/em crise," por vezes, os "debaixo" cobram seu lugar na arena do currículo. Ou seja, cada campo, categoria ou grupo coloca em jogo suas estratégias de resistência (Foucault 2012). Não são poucas as sensações de ameaça uns aos outros. Não se pode desprezar os conflitos entre os marginalizados. Voltando à metáfora da "fronteira": qualquer aproximação em direção a ela nos coloca em contato com muros, policiamentos e a exacerbação das diferenças (que, ademais, sempre estiveram próximas). Como se aproximar da fronteira sem o intuito de dominar o "estrangeiro"? É possível estar nas fronteiras com o objetivo do diálogo, da solidariedade com o "outro", o "estranho"? Enfim, pode o Ensino de Artes Visuais encontrar-se com as questões relativas aos estudos de gênero e sexualidade e "ouvi-los", sem o receio de "perder terreno" ou de confundir sua "identidade"? 
NOTAS

1 Disponível em http://performatus.net/entrevistas/entrevista-beth-moyses/

${ }^{2}$ No Brasil diz respeito aos $1^{\circ}$ ao $5^{\circ}$ anos do Ensino Fundamental, perfazendo, aproximadamente, dos 6 aos 10 anos de idade. O chamado Ensino Fundamental vai até o $9^{\circ}$ Ano.

${ }^{3}$ Como a própria autora propõe na p. 284: "Refiro-me aqui mais especificamente às produções canônicas da arte ocidental."

${ }^{4}$ Lésbicas, Gays, Bissexuais, Travestis, Transexuais, Transgêneros, Queer, Intersexuais e Assexuados/as.

${ }^{5}$ No Brasil, é o período posterior ao Ensino Fundamental. Organizado de 3 a 4 anos.

${ }^{6} \mathrm{Na}$ dissertação de Mestrado realizamos levantamentos em busca de diversas relações (Arte - ensino da arte gênero - sexualidade - anos iniciais). Estes nos ajudaram a encontrar Loponte e Dias, por exemplo.

${ }^{7}$ Esta categoria foi incluída tendo em vista a Lei 11.645/2008.

${ }^{8}$ Terminologia utilizada no mesmo.

${ }^{9}$ Trecho do documento.

${ }^{10}$ Contudo, cada trimestre é guiado por uma por um conjunto de elementos formais.

${ }^{11}$ Termo utilizado no documento.

${ }^{12}$ Exemplos: Mestre Vitalino, Nhô Caboclo, Ana das Carrancas, Antônio Poteiro.

${ }^{13} \mathrm{Na}$ maioria das escola brasileiras, a disciplina é nominada "Arte", enquanto área do conhecimento; resultado de conquistas de arte-educadores na Lei de Diretrizes e Bases da Educação Nacional (LDBEN 9.394/1996). Docentes podem ensinar a partir de sua área de formação - Artes Visuais, Dança, Música e Teatro.

\section{REFERÊNCIAS}

Araújo, Débora C. de \& Santos, Dayana B. C. dos. 2009. "Sexualidades e Gêneros: questões introdutórias". In Paraná/Secretaria de Estado da Educação/Superintendência de Educação/Departamento da Diversidade/Núcleo de Gênero e Diversidade Sexual. Sexualidade. Curitiba: SEED — Pr.

Ariès, Philippe. 1981. História Social da Criança e da Família. Rio de Janeiro: LTC Editora.

Barbosa, Ana Mae, org. 2012a. Inquietações e mudanças no Ensino de Arte. 7 ed. São Paulo: Cortez.

- 2012b. Arte-educação no Brasil. 7 ed. São Paulo: Perspectiva,

- 2012c. A Imagem no Ensino da Arte: anos 80 e novos tempos. 8 ed. São Paulo: Perspectiva.

Battcock, Gregory, org. 1986. A Nova Arte. São Paulo: Perspectiva.

Bourdieu, Pierre. 1990. "O campo científico". In: Ortiz, R. e Fernandes, F. (Coord.). Pierre Bourdieu - Sociologia, 122-155. 2. ed. São Paulo: Ática.

Brasil: Secretaria de Educação Fundamental. 1997. Parâmetros curriculares nacionais: Arte. — Brasília: MEC/SEF.

- 1998. Parâmetros curriculares nacionais: Temas Transversais - Pluralidade Cultural, Orientação Sexual. - Brasília: MEC/SEF.

Butler, Judith. 2015. Problemas de Gênero: feminismo e subversão da identidade. $8^{a}$ ed. Rio de Janeiro: Civilização Brasileira. 
Canton, Katia. 2011. Da Política às Micropolíticas. (Coleção Temas da Arte Contemporânea). São Paulo: Martins Fontes.

Carvalho, Marília P. 1999. No Coração da Sala de Aula: gênero e trabalho docente nas séries iniciais. São Paulo: Xamã.

Cauquelin, Anne. 2005. Arte Contemporânea: uma introdução. São Paulo: Martins Fontes.

César, Maria R. de A. 2009. "Lugar de Sexo é na Escola? Sexo, sexualidade e educação sexual." In Paraná/Secretaria de Estado da Educação/Superintendência de Educação/ Departamento da Diversidade/Núcleo de Gênero e Diversidade Sexual. Sexualidade. Curitiba: SEED — Pr.

Coli, Jorge. 2006. Arte (Coleção Primeiros Passos). São Paulo: Brasiliense.

DiaS, Belidson. 2006. "Acoitamentos: os locais da sexualidade e gênero na arte/educação contemporânea". Visualidades-Revista do Programa de Mestrado em Cultura Visual-Dossiê Cultura Visual 4 (1): 101-131.

Felipe, Jane. 2006. “Afinal, quem é mesmo pedófilo?". Cadernos Pagu 26: 201-223.

Foucault, Michel. 1987. Vigiar e punir: nascimento da prisão. Petrópolis: Vozes.

- 2012. História da Sexualidade: A vontade de saber. $22^{a}$ reimpressão. São Paulo: Graal.

Goodson, Ivor. 1997. A Construção Social do Currículo. Lisboa: EDUCA. Currículo 3.

Hooks, Bell. 2013. Ensinando a Transgredir: educação como prática da liberdade. São Paulo: Martins Fontes.

Krauss, Rosalind. 2001. Caminhos da escultura moderna. São Paulo: Martins Fontes.

Kaercher, Gládis E. P. da S. \& Dalla Zen, Maria I. H. 2010. "Interpretações de Crianças sobre as Representações de Feminilidade e Masculinidade na Literatura Infantil". In Anais do IX Seminário Internacional Fazendo Gênero, Florianópolis, UFSC, 23 a 26 de agosto.

Loponte, Luciana Gruppelli. 2008. "Pedagogias visuais do feminino: arte, imagens e docência". Currículo sem fronteiras 8 (2): 148-164.

- 2002. "Sexualidades, artes visuais e poder: pedagogias visuais do feminino". Estudos feministas $10(2): 283-300$.

Louro, Guacira L. 1999. Gênero, sexualidade e educação: Uma perspectiva pós-estruturalista. $3^{a}$ ed. Petrópolis: Vozes.

Louro, Guacira L. 2009. "Pensar a Sexualidade na Escola". In Paraná/Secretaria de Estado da Educação/Superintendência de Educação/ Departamento da Diversidade/Núcleo de Gênero e Diversidade Sexual. Sexualidade. Curitiba: SEED — Pr.

- 2011. "Educação e docência: diversidade, gênero e sexualidade". Formação Docente, Belo Horizonte 3 (4): 62-70.

- 2012. "Os estudos queer e a educação no Brasil: articulações, tensões, resistências". Revista Semestral do Departamento e do Programa de Pós-Graduação em Sociologia da UFSCar 2 (2): 363.

- 2015. Um Corpo Estranho: ensaios sobre sexualidade e teoria queer. $2^{\mathrm{a}}$ ed. Belo Horizonte: Autêntica.

Moreau, Arthur. 2014. “Entrevista com Beth Moysés". eRevista Performatus 2 (8).

Moruzzi, Andrea B. 2010. “Infâncias: necessárias articulações entre gênero e sexualidade e contribuições dos Cadernos Pagu". In Anais do IX Seminário Internacional Fazendo Gênero, Florianópolis, UFSC, 23 a 26 de agosto.

Munanga, Kabenguele. 2015. Negritude: usos e sentidos. $3^{\mathrm{a}}$ ed. Belo Horizonte: Autêntica.

Nogueira, Monique Andries. 2008. Formação Cultural de Professores ou a Arte da Fuga. Goiânia: Editora da UFG. 
Richter, Ivone Mendes. 2000. “Interculturalidade e estética do Cotidiano no Ensino das Artes Visuais". Tese de Doutorado. Campinas: Faculdade de Educação.

Sardelich, Maria Emilia. 2006. "Leitura de imagens, cultura visual e prática educativa". Cadernos de pesquisa 36 (128): 451-472.

Scott, Joan W. 1995. "Gênero: uma categoria útil de análise histórica". Educação \& Realidade, 20 (2): 71-99.

Silva, Aracy L. da \& Grupioni, Luís D. B. 1995. A temática indígena na escola: novos subsídios para professores de $1^{\circ}$ e $2^{\circ}$ graus. Brasília: MEC/MARI/UNESCO.

Souza, Érica Renata. 2006. "Marcadores sociais da diferença e infância: relações de poder no contexto escolar". Cadernos Pagu 26: 169-199.

\section{Cómo citar este artículo:}

Sombrio de Souza, Edvandro Luise y Monique Andries Nogueira. 2017. “Diversidade sexual e de gênero no ensino de artes visuais para as infâncias: formalismo como elemento de estabilidade nos currículos". Cuadernos de Música, Artes Visuales y Artes Escénicas 12 (2): 149-172. https://doi.org/10.11144/Javeriana.mavae12-2.cdmd 